\title{
Comparison of Surgical Outcomes for Treatment of Maxillary Sinus Inverted Papilloma: Endoscopic Prelacrimal Recess Approach versus Caldwell-Luc Approach
}

\author{
Yeong Jun Park ${ }^{1}$ Byung Whoo Park ${ }^{1}$, Tae Kyung Suh${ }^{1}$, Mi Ra Kim ${ }^{1}$, Sang-Yeon Kim ${ }^{1}$, \\ Shin Hye Kim ${ }^{1}$, Moo Jin Baek ${ }^{1}$, Myoungjoo Kang ${ }^{2}$, and Yong Wan Kim ${ }^{1}$ (D) \\ ${ }^{1}$ Departments of Otolaryngology-Head and Neck Surgery, ${ }^{2}$ Hemato-Oncology, Inje University College of Medicine, \\ Haeundae Paik Hospital, Busan, Korea
}

상악동 기원의 반전성 유두종의 수술법에 따른 결과 비교:

전누골와 접근법과 Caldwell-Luc 접근법

박영준 $^{1} \cdot$ 박병후 $^{1} \cdot$ 서태경 $^{1} \cdot$ 김미라 $^{1} \cdot$ 김상연 $^{1} \cdot$ 김신혜 $^{1} \cdot$ 백무진 $^{1} \cdot$ 강명주 $^{2} \cdot$ 김용완 $^{1}$

인제대학교 의과대학 해운대백병원 이비인후과학교실, ${ }^{1}$ 혈액종양내과학교실 ${ }^{2}$

\author{
Received January 9, 2020 \\ Revised June 4, 2020 \\ Accepted June 9, 2020 \\ Address for correspondence \\ Yong Wan Kim, MD, PhD \\ Department of Otolaryngology \\ Head and Neck Surgery, \\ Inje University College of Medicine, \\ Haeundae Paik Hospital, \\ 875 Haeun-daero, Haeundae-gu, \\ Busan 48108, Korea \\ Tel $+82-51-797-2290$ \\ Fax $+82-51-797-0298$ \\ E-mail kimyw@paik.ac.kr
}

Background and Objectives Endoscopic prelacrimal recess approach (PLRA) was introduced to treat maxillary sinus inverted papilloma (IP) without sacrificing the inferior turbinate and nasolacrimal duct. This study aimed to compare surgical outcomes of prelacrimal recess approach with the conventional Caldwell-Luc approach (CLA) to remove IP of maxillary sinus and to evaluate the usefulness of the PLRA.

Subjects and Method We retrospectively reviewed medical records of 51 patients who were treated in our institution for IP of nasal cavity and sinuses between March 2010 and June 2019. Twenty patients had maxillary sinus IP. Sixteen patients underwent endoscopic sinus surgery combined with either CLA $(n=8)$ or PLRA $(n=8)$. Demographic data, surgical technique, site of IP origin, intra- and postoperative complications, duration of follow-up, recurrence rate and pathologic diagnosis were reviewed.

Results IP was the pathologic diagnosis for all 16 cases. Gross total removal was achieved in all cases. The mean follow-up period was 20.1 months in CLA group and 12.5 months in PLRA group. There was one case of massive bleeding during operation requiring transfusion and postoperative ICU care in CLA group. On postoperative follow-up, two patients from the CLA group had recurrence during the follow-up period. One patient had numbness around the gingival area, another patient had transient wound dehiscence, and another had persistent oro-antral fistula. In PLRA group, one patient had periorbital swelling after blowing nose; otherwise, no other patient from the PLRA group developed subjective complaints after surgery.

Conclusion Endoscopic prelacrimal recess approach showed lower complication rates and recurrence rates compared to CLA. PLRA is a safe and effective method for the excision of primary maxillary sinus IP. Korean J Otorhinolaryngol-Head Neck Surg 2021;64(3):161-8

Key Words Maxillary sinus - Inverted papilloma - Minimally invasive surgical procedures · Prelacrimal recess approach.

This is an Open Access article distributed under the terms of the Creative Commons Attribution Non-Commercial License (https://creativecommons.org/licenses/by-nc/4.0) which permits unrestricted non-commercial use, distribution, and reproduction in any medium, provided the original work is properly cited. 


\section{서 론}

반전성 유두종은 비부비동에 발생하는 종양의 $0.4 \sim 7 \%$ 를 차지하며 비부비동의 양성 종양 중 가장 흔하다. 반전성 유두 종은 조직학적으로 양성 종양이지만 높은 재발율을 보이며 일부에서 악성화를 보이는 특징이 있다. ${ }^{1)}$ 치료는 병변의 완전 한 절제이며, 절제 시 기시부의 정상 점막을 충분히 포함하지 않으면 조기 재발의 가능성이 있다. ${ }^{2)}$

상악동에서 기원한 반전성 유두종을 제거하기 위해 기본적 으로 중비도 상악동 개방술이 이용될 수 있으며 하비도 상악 동 개방술(inferior meatal antrostomy), 측비절개술을 통한 상악골 내측절제술(medial maxillectomy via lateral rhinotomy), 내시경적 상악골 내측절제술(endoscopid medial maxillectomy), Caldwell-Luc 수술, 내시경하 전누골와 접근 법(endoscopic prelacrimal recess approach, PLRA) 등 다 양한 접근법이 알려져 있다. ${ }^{3)}$

과거에는 측비절개술을 통한 상악골 내측절제술과 같은 광범위한 근치술이 선호되었으나, 이는 하비갑개와 코눈물관 을 제거하므로 비강 내 공기유동에 변화를 주고 유루증을 유 발할 수 있다. 1990년대 이후로는 내시경의 발달과 navigation system의 도입으로 비내시경을 이용한 수술이 표준 술 식으로 여겨지고 있다. ${ }^{45)}$ 중비도 상악동 개방술은 가장 기본
적인 술식이지만 상악동의 전벽, 내측벽 및 하벽의 병변을 노 출하는 데 한계가 있다. ${ }^{6}$ Caldwell-Luc 수술은 견치와를 통한 접근으로 비강의 생리적 기능을 보존하고 보다 넓은 시야를 확보할 수 있지만 안면부 감각저하나 구강상악동 누공 등의 문제가 발생할 수 있다. ${ }^{7,8}$ 최근에는 코눈물관과 하비갑개를 보존하여 비강의 생리적 기능을 보존하면서 상악동 내 병변을 제거하기 위한 방법으로 내시경하 전누골와 접근법이 소개되 었고 널리 사용되고있다. ${ }^{9-11)}$

저자들은 상악동에서 기원한 반전성 유두종으로 진단된 환자들에 대해 중비도 상악동 개방술과 함께 시행한 전누골 와 접근법의 안전성과 효용성을 Caldwell-Luc 수술법과 비교 하여 보고하는 바이다.

\section{대상 및 방법}

\section{대 상}

후향적 연구로 2010년 3월 2019년 6월까지 수술 전 비내 시경 및 영상학적 검사상 반전성 유두종이 의심되어 수술을 시행한 환자를 대상으로 하였다. 51명의 환자가 비강 내 반전 성 유두종으로 수술을 시행 받았으며, 이중 병변이 상악동 내에 위치한 경우는 20명이 있었다. 연구는 중비도 상악동 개 방술 만으로 병변의 완전제거가 불가능하여 추가적인 접근법
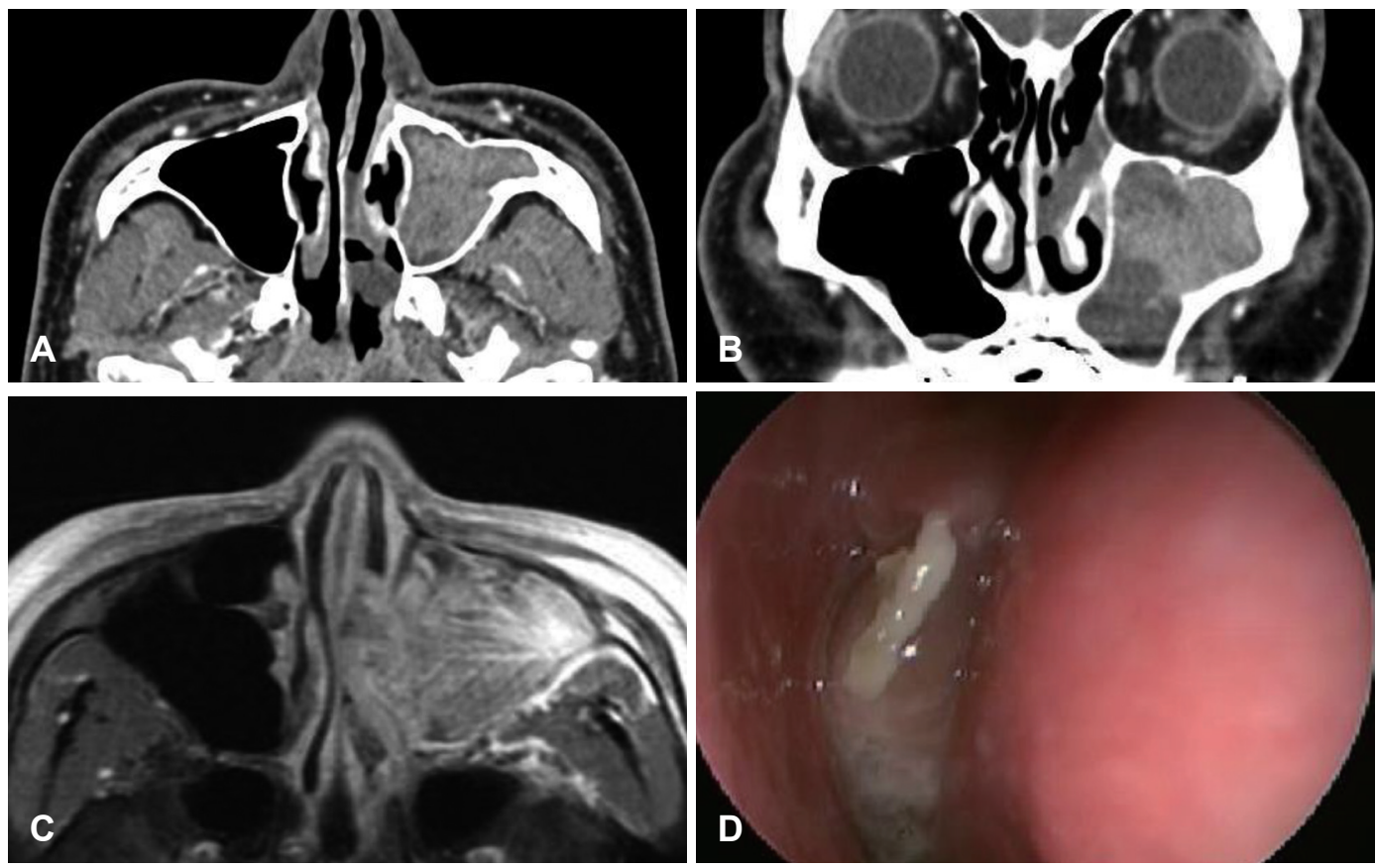

Fig. 1. Representative image of a patient who underwent prelacrimal recess approach. Preoperative CT and MRI scans showing a soft tissue density extending from the left maxillary sinus through ostium into the nasal cavity. Axial CT scan shows osteophytic lesion with enhancing soft tissue lesion in the posterolateral aspect of the left maxillary sinus (A). Coronal view image of the same patient (B). Axial view of T1-weighted contrast-enhanced MRI shows heterogenously enhancing soft tissue lesion in left ostiomeatal unit \& maxillary sinus (C). Nasal endoscopy showing papillomatous lesion extruding from the middle meatus (D). 
이 필요하였던 16 의 환자를 대상으로 진행하였다(Fig. 1). 수 술은 모두 동일한 술자(YW Kim)에 의해 시행되었다. 2014년 6월 이전에 수술을 받은 8명은 Caldwell-Luc 접근법을 이용 하여 병변을 제거하였다. 2014년 11월부터 모든 case를 전누 골와 접근법을 이용하였으며, 8 명이 수술을 시행받았다. 환자 의 성별과 나이, 수술명, 수술 시간, 출혈량, 재원일수, 추적 관찰 기간, 조직학적 진단 및 편평상피세포암의 유무, 과거의 부비동 수술 여부, 수술 중과 수술 후 합병증 여부에 대해 조 사하였다. 모두 일측성 병변이었으며 수술 후 조직학적으로 반전성 유두종으로 확인되었다. 본 연구는 인제대학교 해운 대백병원 기관생명윤리위원회(IRB 202010004)의 연구승인 을 받았다.

\section{수술 방법}

\section{Caldwell-Luc 접근법}

전신마취 하 환측 비강을 관찰하여 중비도 상악동 개방술 을 시행한다. 상악동 내의 병변을 확인하고 관찰 가능한 범 위 내에서 종물을 제거하고, 동결절편검사를 통해 반전성유 두종의 소견을 얻었다. 제거가 용이하지 않은 부분에 있어서 Caldwell-Luc 접근법을 이용하였다. 환측 상악 잇몸에서 5 $\mathrm{mm}$ 떨어진 구강점막에 $3 \mathrm{~cm}$ 수평절개를 가한다. 골막하 박 리를 시행하고 상악골의 전벽을 트로카(trocar) 등으로 개방 하여 상악동 내로 접근하였다. 큐렛, 보비, 미세흡입절삭기, 드릴 등을 이용하여 상악동 내부의 병변과 부착부위를 제거 하고 주변의 정상점막을 제거하였다. 절제연을 동결절편검사 를 통하여 남은 병변이 없음을 확인하였다. 수술 후 구강점막 을 흡수성 봉합사로 봉합하였다.

\section{전누골와 접근법}

전신마취 하 환측 비강에서 우선 중비도 상악동 개방술을 시행하고 동결절편검사를 통해 반전성 유두종 소견을 얻었다. 관찰 가능한 범위 내에서 종물을 제거하였다. 제거가 용이하 지 않은 부분이 있을 경우 전누골와 접근법을 다음과 같은 방법으로 시행하였다. 하비갑개의 전부착부에 서 보비로 수 직 절개를 가한 후, 하비갑개 및 하비도 외측벽의 점막을 골 막하 박리를 시행한다. 코눈물관을 확인하고 하비갑개의 점 막은 봉합사를 통하여 비중격에 고정한다. 다이아몬드 버 (burr)를 이용하여 하비갑개 골부의 일부 및 하비도의 외측 벽을 제거 후 미세흡입절삭기를 통하여 상악동 내로 접근하였 다. 큐렛, 보비, 미세흡입절삭기, 드릴 등을 이용하여 상악동 내 병변과 부착부위를 모두 확인하고 제거하였으며 주변점막을 제거하였다. 절제연에서 동결절편검사를 시행하여 남은 병변
이 없음을 확인하였다. 마지막으로 비중격에 고정한 봉합사 를 제거하고 하비갑개의 점막을 원위치시킨 후 봉합하였다 (Fig. 2).

\section{출혈량의 계산}

출혈량은 수술 중 시행한 suction drain의 총 부피에서 관 류용으로 사용한 증류수와 생리식염수의 부피를 제외하여 계산하였다.

\section{통계 분석}

통계는 SPSS 프로그램(Version 25.0, IBM Corp., Armonk, $\mathrm{NY}, \mathrm{USA}$ )을 사용하여 각 군의 환자의 성별과 합병증 발생 여 부, 재발 여부 등의 범주형 자료의 차이를 판단하기 위해 Fisher's exact test를 이용하였고 환자의 나이, 추적 관찰 기간, 수 술 시간, 출혈량 및 재원일수와 같은 연속형 자료에 대해 Mann-Whitney U 검정을 시행하였으며 $p$ 값이 0.05 미만일 때 통계적으로 유의하다고 판단하였다.

\section{결 과}

총 16 명의 환자가 연구에 포함되었다. 환자를 수술 방법에 따라 Caldwell-Luc approach(CLA)군과 PLRA군으로 나누 었다. 각 군의 대상 환자는 8 명이었으며, 환자의 평균나이는 CLA군에서 54.6(10.5)세, PLRA군에서 56.4(13.9)세였다. 성 비는 남성이 더 많았으며, 이전에 부비동 수술을 받은 환자는 없었다. 평균 추적 관찰 기간은 CLA군에서 20.1개월(1 60개 월), PLRA군에서 12.5개월(2 28개월)이었다. 두 군에서 평균 나이 $(p=0.505)$ 와 성비 $(p=1.000)$, 추적 관찰 기간 $(p=0.721)$ 은 통계적으로 유의미한 차이는 없었다. 모든 환자에서 수술 후 조직검사상 반전성 유두종에 합당한 소견을 보였고, 편평상 피세포암으로 진단된 경우는 없었다(Table 1).

CLA군에서 평균 수술 시간은 180분[95\% confidence interval(CI) 132.20 227.79 min], 수술 중 출혈양은 $561 \mathrm{~mL}$ (95\% CI 8.91 1114.19 mL)였으며, 수술 후 평균 3.5일 $(95 \%$ CI 2.39 4.61일)째 퇴원하였다. 2예에서 추적 관찰 기간 내 재발 을 시사하는 소견을 보였다. 1 예에서 1 개월 이내에 상악동의 상벽에서 조직학적으로 재발이 확인되었고 재발이 확인된 1 개월 이내에 재수술을 시행받았다. 환자는 두 번째 수술 후 14 개월까지 외래 추적 관찰하였고 재발을 시사하는 소견은 없었다. 다른 1 예에서는 수술 후 11 개월째 시행한 부비동 전 산화단층촬영에서 좌측 상악동에 조영 증강되는 종괴가 발 견되었다. 수술 중 합병증으로 1예에서 수술 도중 약 2500 $\mathrm{mL}$ 의 출혈이 있었고 수술 중 농축적혈구 7단위를 포함한 

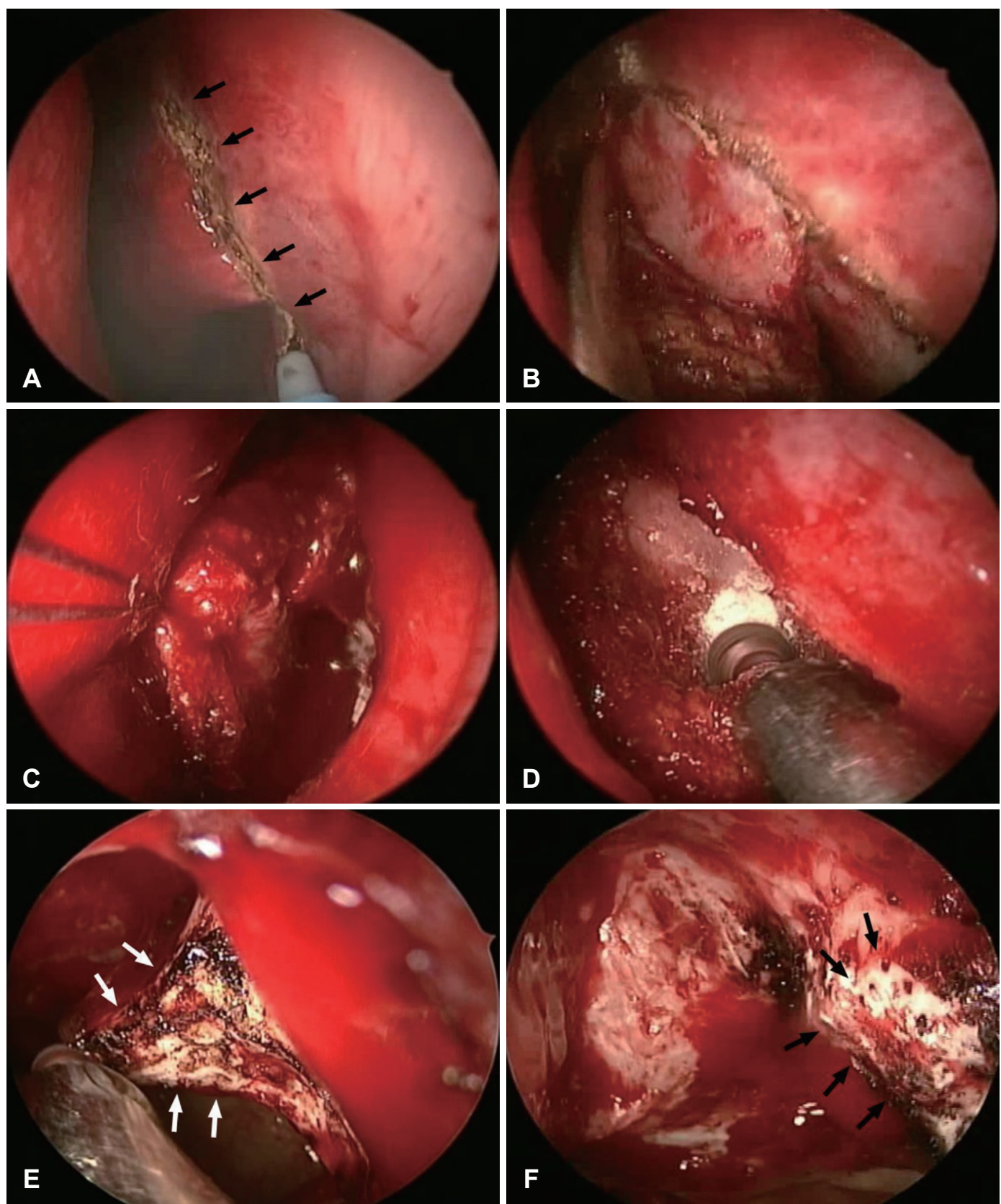

Fig. 2. Surgical procedure of prelacrimal recess approach for left maxillary sinus IP. Vertical incision along the anterior end of inferior turbinate (arrows) (A) and elevation of the nasal mucosa from the lateral nasal wall (B). Suture the nasal mucosa to the nasal septum (C). Removal of the lateral nasal wall by diamond burr (D). Removal of the maxillary sinus pathology and drilling around the osteophytic lesion (arrows) at the anterior aspect of the left maxillary sinus (E). Endoscopic view of the maxillary sinus after removal of IP (arrows) (F). IP: inverted papilloma.

혈구제제를 수혈받았다. 수술 후 2일간 중환자실에서 인공호 흡기 치료를 시행하였으며 일반병실로 전실하였다. 수술 후 합병증으로 2 예에서 구강상악동 누공이 발생하였고 1 예는 단순봉합을 시행하여 2주 후 완전회복을 보였으나 1예는 수 술 후 10 개월까지 적절한 치료에도 회복되지 않았다. 1 예에서 는 잇몸의 불편감을 호소하였고 이는 3주 후 호전되었다.

PLRA군에서 평균 수술 시간은 232분(95\% CI 181.90 283.09 $\mathrm{min})$, 출혈량은 $526 \mathrm{~mL}(95 \% \mathrm{CI} 178.66 \sim 875.09 \mathrm{~mL})$ 이었으 며 수술 후 약 3.25일째(95\% CI 2.76 3.74일) 퇴원하였다. 추 적 관찰 기간 동안 비내시경상 육아조직이 보이는 경우 조직검 사를 시행하였으며 현재까지 환자들에서는 $30^{\circ}, 70^{\circ}$ 비내시 경상 재발이 의심되는 환자는 발견되지 않았다. 전누골와 접 근법으로 수술받은 환자는 1 예에서 수술 후 10 일 후에 코를 풀고 난 뒤 수술 부위 안와주위 부종이 발생하였고 1 주일 뒤 
호전되었다. 수술 후 코막힘, 유루증, 윗입술 주변의 감각저하, 지속적인 코 안의 건조감 등의 합병증은 발생하지 않았으며 모든 환자에서 수술 후 2개월 이내에 회복된 하비갑개의 점 막을 확인할 수 있었다(Fig. 3). CLA군과 PLRA군에서 수술 시간 $(p=0.161)$, 수술 중 출혈량 $(p=0.645)$, 재원일수 $(p=0.574)$, 추적 관찰 기간 내 재발 여부 $(p=0.467)$, 합병증 발생 여부 $(p=$ 0.569)는 두 군 간에 유의미한 차이를 보이지 않았다(Table 2).

반전성 유두종의 기시부위는 수술 전 영상학적 검사와, 수 술 중 소견을 종합하여 판단하였다. CLA군에서 기시부는 상악동의 상벽, 하벽, 전벽, 상악동 개구부, 외측벽이 각각 1예, 상악동 내측벽에서 2예였으며 PLRA 군에서 기시부는 하벽 과 상벽에서 각각 2예, 전벽 2예, 내측벽에서 2예, 내측벽과 상 벽이 모두 의심되는 경우가 1 예였다. 두 군 모두에서 수술 중 병변의 완전한 노출 및 제거가 불가능했던 경우는 없었다 (Table 3).

모든 환자에서 반전성 유두종은 비강 및 상악동 내에 국한 되어 다른 부비동으로의 침범은 없었고 Krouse's 병기 구분에 따라 CLA군에서 5명은 T2, 3명은 T3에 해당되었고 PLRA군

Table 1. Pateint characteristics

\begin{tabular}{cccc}
\hline Variables & CLA & PLRA & $\begin{array}{c}\text { P- } \\
\text { value }\end{array}$ \\
\hline $\begin{array}{c}\text { Pateint characteristics } \\
\text { No. of patients }\end{array}$ & 8 & 8 & \\
Mean age (SD) & $54.6(10.5)$ & $56.4(13.9)$ & 0.505 \\
$\begin{array}{c}\text { Male:female } \\
\text { History of previous } \\
\text { operation (no.) }\end{array}$ & $6: 2$ & $5: 3$ & 1.000 \\
$\begin{array}{c}\text { Mean follow-up } \\
\text { period (months) }\end{array}$ & $20.1(1-60)$ & $12.5(2-28)$ & 0.721 \\
$\begin{array}{c}\text { Pathological result } \\
\text { (no. of cases) }\end{array}$ & All IP & All IP & \\
\hline
\end{tabular}

CLA: Caldwell-Luc approach, PLRA: endoscopic prelacrimal recess approach, SD: standard deviation, IP: inverted papilloma
에서 3명은 T2, 5명은 T3에 해당하였다(Table 4).

\section{고 찰}

반전성 유두종은 양성종양이지만, 일부에서 악성화를 보이 는 경향이 있으며 완전한 절제가 이루어지지 않으면 조기재 발의 가능성이 있다. 따라서 수술시 기시부를 포함한 병변의 완전한 노출 및 정상 점막을 포함한 병변의 제거가 중요하다. 2000년대 이전까지는 상악동에 발생한 반전성유두종의 수 술적 접근법으로 안면중앙 접근법, 혹은 측비절개술을 통한 상악골 내측절제술 등 비외접근법을 통한 수술이 선호되었 다.") 그러나 1990년도 이후 내시경의 발달로, 내시경적 상악 골 내측절제술 등 내시경적 접근법이 전두동과 접형동 기원 의 병변의 제거가 용이하며, 상악동기원의 반전성유두종 제거 에 있어 비외접근법과 유사한 재발율을 보이며 널리 사용되 기 시작하였다. 2016년 $\mathrm{Kim}$ 등 ${ }^{12)}$ 이 시행한 메타분석연구에 의하면 외부접근법에 비해 내시경적 수술이 Krouse stage 1 에서 재발율이 유의미하게 낮음을 보고한 바 있다. 하지만 Krouse stage 4의 경우에서는 내시경적수술시 반전성유두종 의 재발위험이 1.92 배 높은 것으로 나타났으며, 상악동에 국 한된 경우가 포함되는 Krouse stage 2, 3의 경우 유의미한 차 이는 없는 것으로 보고되었다.

가장 기본적인 상악동 내시경 수술로 중비도 상악동 개방 술이 있다. 하지만 이는 상악동의 전벽과 내측벽, 하벽에 접근 에 제한이 있다는 단점이 있다. 내시경이 널리 사용되기 이전 부터 사용되던 Caldwell-Luc 수술은 1893년 미국 New York 의 외과의사 Caldwell ${ }^{13)}$ 에 의해 급성 부비동염의 치료로 보 고된 바 있다. 하비도 상악동 개방술과 함께, 구강점막을 절개 하여 견치와를 통해 상악동을 개방하고 배액하는 술식으로 보고되었다. 1897년 프랑스의 외과의사인 Henry Luc 역시 만
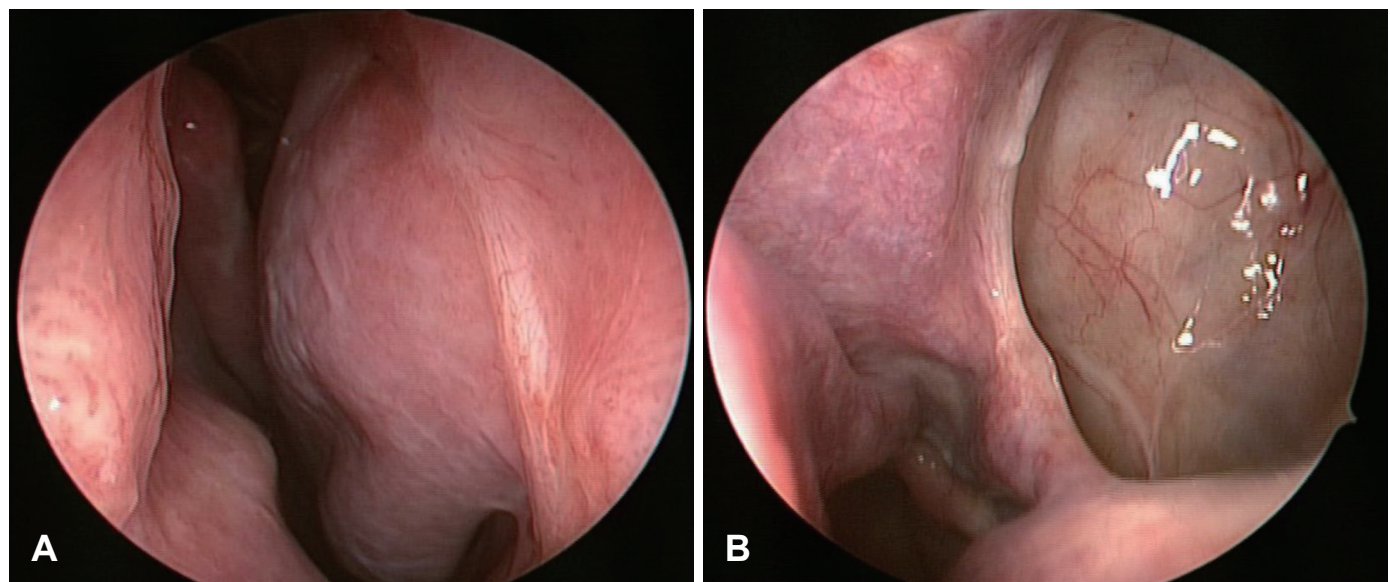

Fig. 3. Endoscopic view at 2 months after surgery of the same patient. Preserved nasal cavity mucosa and the inferior turbinate (A). The maxillary sinus opening remains clear $(\mathrm{B})$. 
Table 2. Surgical outcomes according to surgical approach

\begin{tabular}{lccc}
\hline \multicolumn{1}{c}{ Variables } & CLA $(95 \% \mathrm{Cl})$ & PLRA $(95 \% \mathrm{Cl})$ & $\mathrm{p}$-value \\
\hline Surgical outcomes & & & 0.161 \\
Operation time $(\mathrm{min})$ & $180(132.20-227.79)$ & $232.5(181.90-283.09)$ & 0.645 \\
Bleeding amount $(\mathrm{mL})$ & $561.3(8.91-1114.19)$ & $526.9(178.66-875.09)$ & None \\
Failure of gross total removal & None & $3.25(2.76-3.74)$ & 0.574 \\
Hospital stay (POD) & $3.5(2.39-4.61)$ & 0 & 0.467 \\
Recurrence & 2 & 0 & 0.569 \\
SCC from IP & 0 & Periorbital emphysema (1) \\
Complication & Intraoperative bleeding (1) & \\
& Oro-antral fistula (2) & & \\
\end{tabular}

Table 3. Site of origin based on operative and radiological findings

\begin{tabular}{lcc}
\hline \multicolumn{1}{c}{ Site of origin } & CLA & PLRA \\
\hline Anterior wall & 1 & 2 \\
Posterior wall & 1 & 0 \\
Lateral wall & 1 & 0 \\
Medial wall & 3 & 2 \\
Superior wall & 1 & 2 \\
Inferior wall & 1 & 1 \\
Med, and sup. wall & 0 & 1
\end{tabular}

CLA: Caldwell-Luc approach, PLRA: endoscopic prelacrimal recess approach

Table 4. Krouse stage of the patients

\begin{tabular}{ccc}
\hline Krouse stage & CLA & PLRA \\
\hline T1 & 0 & 0 \\
T2 & 5 & 3 \\
T3 & 3 & 5 \\
T4 & 0 & 0 \\
\hline
\end{tabular}

CLA: Caldwell-Luc approach, PLRA: endoscopic prelacrimal recess approach

성 부비동염의 수술적 치료로서 비슷한 술식을 보고한 바 있 으며, 중비도 상악동 개방술을 동시에 시행하였다. 이러한 술 식은 수정을 거듭하며 Caldwell-Luc surgery로 자리잡게 되 었다.14) Caldwell-Luc 접근법은 상악동 내측벽 및 안와하벽, 익돌구개와를 잘 노출할 수 있는 술식으로 알려져있다. 그러 나 $\mathrm{Low}^{8)}$ 가 184 명의 환자에 대해 약 34 개월간 추적 관찰한 결과, Caldwell-Luc 접근법은 안면 부종(61.9\%), 안면의 감 각저하나 통증 $(46 \%)$, 잇몸의 감각저하나 통증(30.9\%)의 빈 도가 비교적 흔하고, 구강상악동누공 $(0.4 \%)$ 등이 발생할 수 있다. 이 중 안면과 잇몸의 감각저하는 안와하신경의 분지의 손상에 의한 것으로 생각되어지고 있다. 전누골와 접근법을 이용할 경우 안와하신경과 그 분지의 직접적인 노출이 없으 므로 이러한 합병증의 빈도가 낮으며, 대부분 일시적이다.

내시경하 전누골와 접근법은 2007년 Zhou 등ㅎㅇㅇㅣ 상악동의
반전성 유두종을 포함한 양성종양에 대한 수술법으로써, 하 비갑개와 비루관을 보존하는 술식으로 발표하였다. 이후 여 러 연구에서 유루증, 건조감 등의 증상이 나타나지 않고 재 발률도 낮았음을 보고하였다. ${ }^{3,10,11)}$ 술식은 공통적으로 하비 갑개의 전부착부에 하비도 외측벽의 점막을 박리 후, 전비공 (pyriform aperture)과 코눈물관(nasolacrimal duct) 사이에 해당하는 상악동 내측벽인 전누골와(prelacrimal recess)를 제거하여 상악동내로 접근한다. 수술 후에는 하비갑개 전부 착부 점막을 봉합하여 비강의 생리적인 기능과 구조를 보존 할 수 있다. 이러한 접근법은 일반적인 부비동 내시경 수술로 병변의 완전한 제거가 불가능한 만성염증, 진균성 부비동염의 치료뿐만 아니라 ${ }^{15)}$ 전누골와, 치조함요(alveolar recess) 및 관 골함요(zygomatic recess)를 포함한 상악동 내 모든 위치에 서 기원한 종양을 효과적으로 제거할 수 있는 술식으로 보 고되었다.116,17) Zhou 등 ${ }^{10)}$ 은 상악동의 반전성 유두종으로 전 누골와 접근법을 시행받은 71 명의 환자를 대상으로한 다기관 연구를 시행하였다. 병변의 기시부는 대부분이 전벽과 전상 벽, 내측벽이었으며, 전누골와 접근법으로 병변을 제거하는 데 제한이 없었다. 평균 37.3개월(13 134개월)간의 추적 관찰 기 간 내 5 건(7\%)의 재발이 있었으며, 3명(4.2\%)의 환자가 수술 후 비강의 편평상피세포암으로 진단받았다. 수술 중 비루관 의 손상이 발생한 경우는 없었다. 11명(15.4\%)의 환자가 수술 후 코와 윗입술 주변의 감각저하를 호소하였으며, 이중 5명 (7\%)은 수술 후 1 년까지 증상이 지속되었다. 또한 비익과 코 의 경미한 변형이 4 명(5.6\%)의 환자에게서 발생하였다. 본 연 구에서는 수술 후 안면부 감각저하, 유루증 혹은 비강 내 건 조감 등의 증상은 없었고 추적 관찰 기간 내 재발은 없었다.

여러 연구에서 전누골와 접근법의 장점으로 코눈물관과 하비갑개의 손상 없이 상악동의 모든 벽의 병변을 노출할 수 있다는 점을 기술하고 있다. 본 연구 역시 반전성 유두종의 기시부에 따른 수술적 적응증을 두지 않았으며, 상악동 전벽, 
내측벽, 상벽과 하벽을 포함하여 기시부 위치에 관계없이 완 전히 노출하고 제거하는 데 제한이 없었다.

상악동 기원의 반전성 유두종의 수술에 있어서 전누골와 접근법과 다른 수술법들의 치료 성적과 재발을 비교한 연구 는 많지 않다. 최근 Lee 등ㄱㅇㅣ 상악동에 발생한 양성종양의 수술로서 내시경하 전누골와 접근법 $(\mathrm{n}=10)$ 과 Caldwell-Luc $\operatorname{surgery}(n=30)$ 의 치료성적을 비교하였다. 수술 시간, 수술 중 출혈량, 수술 후 재원 기간 등에서 통계적으로 유의미한 차이 는 없었으며, CLA군에서 11 명(37\%)의 환자에서 안면부 감각 저하가 발생하였고, 이 중 2명(7\%)은 수술 후 1년까지 증상이 지속되었으며, 2 명 $(7 \%)$ 의 환자에서 수술 후 안면통증이 발생 하였다. 전누골와 접근법을 시행받은 환자에서는 3명(30\%)에 서 안면부 감각저하가 발생하였고, 모두 3 개월 이내에 증상이 호전되었다. 수술 후 합병증 발생률과 재발율에 있어서 통계적 으로 유의미한 차이를 보이지 않았다.

Mirza 등 ${ }^{18)}$ 에 따르면 63개의 case series 연구를 분석하였 을 때, 비부비동의 반전성 유두종 2297예 중 163예(7.1\%)에서 편평상피세포암이 동반되어 있었다(synchronous). 2047예 중 63예(3.6\%)에서 편평상피세포암이 속발성(metachronous)으 로 발생하였다. 속발성 편평상피세포암의 평균 발생기간은 52 개월(6 180개월)이었다. 또한 484건의 내시경적수술에서 62 건(12.8\%)의 재발을 보였다. 따라서 반전성 유두종은 권고된 수술 후 추적 관찰 기간은 없으나, 오랜 기간 추적 관찰을 요 한다. 본 연구에서는 평균 추적 관찰 기간은 CLA군에서 약 20 개월, PLRA군에서 약 12 개월으로, 속발성 편평상피세포암 의 발생 기간을 고려한다면 보다 장기적인 추적 관찰이 진행 되어야 할 것으로 사료된다.

CLA와 PLRA는 모두 비강 내 생리기능을 변화시키지 않 고 상악동의 병변을 제거할 수 있다는 장점이 있다. 그러나 수 술 후 추적 관찰의 측면에 있어서, 내시경만으로 수술범위를 모두 관찰하는 데 한계가 있다는 단점이 존재한다. 내시경 추 적관찰을 대체할 수단으로 정기적인 영상검사를 시행할 수 있으나, 이에 대한 기준이 명확하지 않다는 한계가 있다.

본 연구는 적은 수의 환자를 대상으로 한 후향적 연구라는 점에서, 수술법 간 비교의 통계적 유의성을 검증하는 데 제한 점이 있다. 또한 동일한 술자에 의해 수술이 시행되었지만, 특 정 시점을 기점으로 하여 두 수술적 접근법의 시행여부에 차 이가 있다는 점 역시 연구의 제한점이 된다. 시점에 따른 외과 의의 실력 차이가 반영되므로 본 연구만으로 수술법의 유용 성에대해 판단하는 데에는 한계가 있다. 향후 상악동 내 반전 성 유두종 환자에게 전누골와 접근법이 적극 활용되어 다른 수술법들의 치료 성적과, 장기적인 추적관찰과 재발에 대한 비교가 이루어져야 할 것으로 사료된다.
전누골와 접근법은 Caldwell-Luc 접근법 모두 상악동 전 벽과 내측벽, 상벽과 하벽을 포함한 병변의 완전제거에 제한 이 없었으며, Caldwell-Luc 접근법에서 2예의 재발이 있었다. 결론적으로 상악동에 발생한 반전성 유두종의 수술에 있어 중비도 상악동 개방술로 충분한 제거가 불가능할 경우, 전누 골와 접근법은 Caldwell-Luc 접근법과 비교하여 구강내 절 개를 시행하지 않고, 하비갑개와 코눈물관을 보존하며 병변 의 완전한 제거가 가능한 술식으로 안전하게 사용될 수 있을 것으로 생각된다.

\section{Acknowledgments}

None.

\section{Author Contribution}

Conceptualization: Yong Wan Kim. Data curation: Yeong Jun Park, Byung Whoo Park, Tae Kyung Suh. Formal analysis: Mi Ra Kim, Sang-Yeon Kim. Methodology: Shin Hye Kim, Moo Jin Baek. Supervision: Myoungjoo Kang, Yong Wan Kim. Validation: Myoungjoo Kang, Yong Wan Kim. Writing — original draft: Yeong Jun Park, Yong Wan Kim. Writing — review \& editing: Myoungjoo Kang, Yong Wan Kim, Moo Jin Baek.

\section{ORCID}

Yong Wan Kim https://orcid.org/0000-0002-6010-312X

\section{REFERENCES}

1) Min IK, Koo BS, Park CH, Kim AY, Park SW, Rha KS. Inverted papilloma of the nose and paranasal sinuses: An analysis of 102 cases. Korean J Otolaryngol-Head Neck Surg 2003;46(8):659-64.

2) Ungari C, Riccardi E, Reale G, Agrillo A, Rinna C, Mitro V, et al. Management and treatment of sinonasal inverted papilloma. Ann Stomatol (Roma) 2016;6(3-4):87-90.

3) Nakayama T, Asaka D, Okushi T, Yoshikawa M, Moriyama H, Otori N. Endoscopic medial maxillectomy with preservation of inferior turbinate and nasolacrimal duct. Am J Rhinol Allergy 2012;26(5):405-8.

4) Peng P, Har-El G. Management of inverted papillomas of the nose and paranasal sinuses. Am J Otolaryngol 2006;27(4):233-7.

5) Philpott CM, Dharamsi A, Witheford M, Javer AR. Endoscopic management of inverted papillomas: Long-term results--the St. Paul's Sinus Centre experience. Rhinology 2010;48(3):358-63.

6) Zhao Y, Cheng J, Yang J, Li P, Zhang Z, Wang Z. Modified endoscopic inferior meatal fenestration with mucosal flap for maxillary sinus diseases. Wideochir Inne Tech Maloinwazyjne 2018;13(4):533-8.

7) Lee JJ, Ahmad Z AM, Kim D, Ryu G, Kim HY, Dhong HJ, et al. Comparison between endoscopic prelacrimal medial maxillectomy and Caldwell-Luc approach for benign maxillary sinus tumors. Clin Exp Otorhinolaryngol 2019;12:287-93.

8) Low WK. Complications of the Caldwell-Luc operation and how to avoid them. Aust N Z J Surg 1995;65(8):582-4.

9) Zhou B, Han DM, Cui SJ, Huang Q, Wei YX, Liu HC, et al. Endoscopic nasal lateral wall dissection approach to maxillary sinus. Zhonghua Er Bi Yan Hou Tou Jing Wai Ke Za Zhi 2007; 42(10):743-8.

10) Zhou B, Huang Q, Sun J, Li X, Zhang W, Cui S, et al. Resection of inverted papilloma of the maxillary sinus via a prelacrimal recess approach: A multicenter retrospective analysis of surgical efficacy. Am J Rhinol Allergy 2018;32:518-25. 
11) Zhou B, Han DM, Cui SJ, Huang Q, Wang CS. Intranasal endoscopic prelacrimal recess approach to maxillary sinus. Chin Med J (Engl) 2013;126(7):1276-80.

12) Kim JS, Kwon SH. Recurrence of sinonasal inverted papilloma following surgical approach: A meta-analysis. Laryngoscope 2017; 127(1):52-8.

13) Caldwell GW. Diseases of the accessory sinuses of the nose and improved of treatment for suppuration of the maxillary antrum. New York Med Jour a Med Record 1893;4

14) Datta RK, Viswanatha B, Shree Harsha M. Caldwell Luc surgery: Revisited. Indian J Otolaryngol Head Neck Surg 2016;68(1):90-3.

15) Lin YT, Lin CF, Yeh TH. Application of the endoscopic prelacrimal recess approach to the maxillary sinus in unilateral maxillary diseases. Int Forum Allergy Rhinol 2018;8(4):530-6.

16) Lin YH, Chen WC. Clinical outcome of endonasal endoscopic prelacrimal approach in managing different maxillary pathologies. PeerJ 2020;8:e8331.

17) Yu QQ, Guan G, Zhang NK, Zhang XW, Jiang Y, Lian YY, et al. Intranasal endoscopic prelacrimal recess approach for maxillary sinus inverted papilloma. Eur Arch Otorhinolaryngol 2018;275(9): 2297-302.

18) Mirza S, Bradley PJ, Acharya A, Stacey M, Jones NS. Sinonasal inverted papillomas: Recurrence, and synchronous and metachronous malignancy. J Laryngol Otol 2007;121(9):857-64. 